\title{
Guidance for Controlling Potential Risks to Workers Exposed to Class B Biosolids
}

This guidance is intended only for controlling health risks to workers from Class B biosolids during handling and land application. This guidance is not intended to address nonoccupational exposure.

DEPARTMENT OF HEALTH AND HUMAN SERVICES

Centers for Disease Control and Prevention

National Institute for Occupational Safety and Health

July 2002 
This document is in the public domain and may be freely copied or reprinted.

\title{
DISCLAIMER
}

Mention of any company or product does not constitute endorsement by NIOSH.

\section{ORDERING INFORMATION}

To receive documents or more information about occupational safety and health topics, contact the National Institute for Occupational Safety and Health (NIOSH) at

\author{
NIOSH—Publications Dissemination \\ 4676 Columbia Parkway \\ Cincinnati, OH 45226-1998
}

Telephone: 1-800-35-NIOSH (1-800-356-4674)

Fax: 1-513-533-8573

E-mail: pubstaft@cdc.gov

or visit the NIOSH Web site at www.cdc.gov/niosh

Publication Number 2002-149

SAFER - HEALTHIER - PEOPLE TM 


\section{Introduction}

Biosolids are the organic residues resulting from the treatment of commercial, industrial, and municipal wastewater (sewage). One purpose of the treatment is to significantly reduce the concentration of disease-causing organisms (also known as pathogens). Treatment also reduces the attractiveness of the residues to insects, birds, and rodents. The product is a material that can be recycled for uses such as adding organic material to the soil.

The U.S. Environmental Protection Agency (EPA) has established two categories of biosolids:

- Class A biosolids have undergone treatment to the point where the concentration of pathogens is reduced to levels low enough that no additional restrictions or special handling precautions are required by Federal regulations [40 CFR ${ }^{*}$ Part 503]. If the Class A biosolids meet exceptional quality requirements for metals content, they may be sold in bags and applied in the same way as other soil conditioners such as peat moss.

- Class B biosolids have undergone treatment that has reduced but not eliminated pathogens. By definition, Class B biosolids may contain pathogens. As a result, Federal regulations for use of Class $\mathrm{B}$ biosolids require additional measures to restrict public access and to limit livestock grazing for specified time periods after land application [40 CFR Part 503]. This allows time for the natural die-off of pathogens in the soil.

Whereas EPA rules [40 CFR Part 503] restrict public access to lands treated with Class B biosolids in order to protect public health, these rules do not apply to workers involved with Class B biosolids handling and land application.

\footnotetext{
${ }^{*}$ Code of Federal Regulations.
}

Workers may come in contact with Class B biosolids during the course of their work. Workers and employers may be well aware of the need for precautions when contacting untreated sewage but less aware of the need for basic precautions when using Class B biosolids. This document provides information, guidance, and recommendations to employers and employees working with Class B biosolids to minimize occupational risks from pathogens. It does not address other potential safety and health issues such as injuries or exposures to chemicals.

\section{How are biosolids used?}

Biosolids are typically treated to Class B or Class A standards at the wastewater (sewage) treatment plant, where a liquid or semi-solid material is produced. In a liquid state, biosolids can be transported by truck to a land application site where they are applied directly to the land using tractors, tank wagons, irrigation systems, or special application vehicles. Alternatively, biosolids may undergo mechanical dewatering that may include the use of polymers. Dewatered and liquid biosolids are often temporarily stored at the treatment plant or application site. Dewatered biosolids are transported and applied to land using front-end loaders, trucks, tractors, or biosolids-spreading equipment. Most biosolids are applied with spreaders in semisolid form and then incorporated into the soil using a disc plow. Workers may come into either direct or indirect contact with biosolids during any phase of the treatment, transport, or application process, or after they are land applied. Currently, more than $50 \%$ of the biosolids generated in the United States is recycled as soil conditioners to improve and maintain productive soils and stimulate plant growth rather than being sent to landfills or incinerated. Biosolids are applied on agricultural land, forestlands, and surface mine reclamation sites. Class A biosolids are also used in horticultural applications. EPA estimates that 7.1 million tons of biosolids were generated for use or disposal in 2000. 


\section{What is in biosolids that requires control of worker exposures?}

There are four major types of human diseasecausing organisms (pathogens) that can be found in sewage: (1) bacteria, (2) viruses, (3) protozoa, and (4) helminths (parasitic worms). Class B biosolids may contain the same types of pathogens as the source sewage, but at reduced concentrations. Both Class A and Class B biosolids may also contain chemicals (including metals) and allergens.

To protect public health, the EPA's 40 CFR Part 503 rule prescribes a restricted period of up to 1 year to limit public access to lands where Class B biosolids have been applied. These EPA restrictions do not apply to occupational access. EPA does recognize that occupational exposure can occur and states that workers exposed to Class B biosolids might benefit from several additional precautions such as use of dust masks when spreading dry materials, the use of gloves when touching biosolids, and routine hand washing before eating, drinking, smoking, or using the bathroom.

The risk of worker exposure to infectious agents in Class B biosolids is likely greatest prior to, during, and immediately after land application of the biosolids. Because the concentration of pathogens declines through natural processes, the potential for pathogen exposure decreases over time.

\section{Do we know these pathogens can cause disease?}

Yes, the association between poor hygiene, raw sewage, and infectious disease is well established. Most of the pathogenic bacteria, viruses, and parasites in biosolids are enteric, which means they are present in the intestinal tracts of humans and animals. Enteric organisms that may be found in biosolids include, but are not limited to, Escherichia coli, Salmonella, Shigella, Campylobacter, Cryptosporidium, Giardia, Norwalk virus, and enteroviruses. Exposure may potentially result in disease (e.g., gastroenteritis) or in a carrier state in which an infection does not clinically manifest itself in the individual but can be spread to others. These enteric organisms are usually associated with self-limited gastrointestinal illness but can develop into more serious diseases in sensitive populations such as immune-compromised individuals, infants, young children, and especially the elderly.

The disease risk is a function of the number and types of pathogens in the Class B biosolids relative to the exposure levels and infective dose. Because data are sparse on what constitutes an infective dose, it is prudent public health practice to minimize workers' contact with Class B biosolids and soil or dusts containing Class B biosolids during production and application, and at land application sites during the period when public access is restricted. Class A biosolids may also present some health risk to workers, since some chemicals and biologic constituents in Class A biosolids are not regulated by the EPA.

\section{Can workers be exposed to pathogens from biosolids?}

Workers could be exposed to pathogens and irritants when working with Class B biosolids during the period when public access is restricted. During a NIOSH field investigation at one biosolids land application and storage site that did not comply with EPA requirements, the following was observed:

- NIOSH interviewed employees who worked in all phases of the biosolids operation. Some 
employees reported repeated episodes of gastrointestinal illness after working with the biosolids, either at the treatment plant or during land application.

- NIOSH observed among workers an inconsistent awareness, provision, and use of protective equipment and hygiene practices appropriate for handling Class B biosolids (or biosolids that do not comply with EPA standards).

- NIOSH collected bulk samples from different locations within the biosolids storage site and found measurable concentrations of fecal coliforms. Fecal coliforms are used as an indicator for the presence of other enteric microorganisms. Enteric bacteria were detected in air samples collected at the land application site.

- The local department of environmental services recently informed NIOSH that biosolids applied at this site intermittently exceeded (by up to 4.5 times) the EPA fecal coliform upper limit for Class B biosolids prior to the NIOSH survey.

- The substandard biosolids were applied at the agricultural site before the monitoring results were received from the laboratory.

EPA reports that high-pressure spray applications may result in some aerosolization of pathogens and that application or incorporation of dewatered biosolids may cause very localized fine particulate/dusty conditions. Also, farm workers may be exposed to biosolids after application and during the restricted period. Ancillary workers (for example, laborers hired to clean trucks that were used to haul biosolids) can be exposed to biosolids. Exposures to substandard biosolids can occur when these materials are loaded and hauled to approved landfills or incinerators for disposal.

Additional study of worker exposures to pathogens and other toxics possibly present in
Class B biosolids is needed. This will reduce scientific uncertainty about these issues and allow further refinement of worker precautions.

\section{What should employers do to prevent work-related illness?}

To protect workers who have direct contact with Class B biosolids and thus are likely to have an exposure to pathogens, employers should provide a basic level of protection, including appropriate measures from those listed below. While the measures are worded to refer to Class B biosolids, most also apply to tasks involving contact with sewage, untreated or partially treated sludge, or substandard biosolids.

\section{Provide basic hygiene recommendations for workers.}

Basic hygiene precautions are important for workers handling biosolids. The following list, originally developed by EPA, provides a good set of hygiene recommendations.

1. Wash hands thoroughly with soap and water after contact with biosolids.

2. Avoid touching face, mouth, eyes, nose, genitalia, or open sores and cuts while working with biosolids.

3. Wash your hands before you eat, drink, or smoke and before and after using the bathroom.

4. Eat in designated areas away from biosolids-handling activities.

5. Do not smoke or chew tobacco or gum while working with biosolids. 
6. Use barriers between skin and surfaces exposed to biosolids.

7. Remove excess biosolids from footgear prior to entering a vehicle or a building.

8. Keep wounds covered with clean, dry bandages.

9. Thoroughly but gently flush eyes with water if biosolids contact eyes.

10. Change into clean work clothing on a daily basis and reserve footgear for use at worksite or during biosolids transport.

11. Do not wear work clothes home or outside the work environment.

12. Use gloves to prevent skin abrasion.

In addition, NIOSH recommends the following steps to provide a more comprehensive set of precautions for use by employers and employees:

\section{Provide appropriate protective equipment, hygiene stations, and training.}

Personal Protective Equipment (PPE).Appropriate PPE should be provided for all workers likely to have exposure to biosolids. The choices of PPE include goggles, splash-proof face shields, respirators, liquid-repellent coveralls, and gloves. Face shields should be made available for all jobs in which there is a potential for exposure to spray or high-pressure leaks, or aerosolized biosolids during land application. Management and employee representatives should work together to determine which job duties are likely to result in this type of exposure, to conduct appropriate on-site monitoring, and to determine which type of PPE is needed in conjunction with a qualified safety and health professional. If respirators are needed, a comprehensive program would include respirator fit-testing and training or retraining.

Hygiene and Sanitation.- - Hand-washing stations with clean water and mild soap should be readily available whenever contact with biosolids occurs. In the case of workers in the field, portable sanitation equipment, including clean water and soap, should be provided. Cabs should be wiped down and cleaned of residual mud (or settled dust) frequently to reduce potential for exposure to biosolids.

Training.-Periodic training on standard hygiene practices for biosolids workers should be conducted by qualified safety and health professionals to cover issues such as the following:

- Frequent and routine hand washing (the most valuable safeguard in preventing infection by agents present in biosolids), especially before eating or smoking

- The proper use of appropriate PPE, such as coveralls, boots, gloves, goggles, respirators, and face shields

- The removal of contaminated PPE and the use of available on-site showers, lockers, and laundry services

- Proper storage, cleaning, or disposal of contaminated PPE

- Instructions that work clothes and boots should not be worn home or outside the immediate work environment

- Prohibition of eating, drinking, or smoking while working in or around biosolids

- Procedures for controlling exposures to chemical agents that may be in biosolids 
Reporting. - Workers should be trained to report potentially work-related illnesses or symptoms to the appropriate supervisory or health care staff. This may aid in the early detection of work-relat ed health effects.

Immunizations. - Ensure that all employees are up-to-date on tetanus-diphtheria immunizations, since employees are at risk of soil-contaminated injuries. Current CDC recommendations do not support hepatitis A vaccination for sewage workers.

\section{Extend good environmental practices to prevent and minimize occupational exposures.}

- Where feasible, substituting Class A biosolids could reduce the pathogen exposure risks during land application compared to applying Class B biosolids. Feasibility may be affected by local customer preferences, since the two types of biosolids vary in the nutrient value they provide to end-users.

- Monitor the source material coming from the wastewater treatment facility. Check monitoring results to assure they meet specified Class B or Class A standards prior to land application operations.

- Monitor stored biosolids prior to application to assure that the biosolids are properly stabilized and that unacceptable regrowth or cross-contamination from substandard material has not occurred.

- Where local conditions permit, inject biosolids below the soil or incorporate (thoroughly mix) into tilled soil. This will minimize post-application worker contact with applied biosolids and prevent resuspension into the air during periods of dryness.

- On windy days, avoid spreading or disturbing dry biosolids (e.g., compost) that would create dust.

- On windy days, avoid spreading biosolids by high-pressure spray.

- Avoid unnecessary mechanical disturbance and contact with land-applied Class B biosolids during the period when public access is restricted.

- Equip heavy equipment used at storage and application facilities with sealed, positive-pressure, air-conditioned cabs that contain filtered air-recirculation units.

- Monitor worker exposures when adjusting precautions to address site-specific issues.

\section{For More Information}

Additional information about biosolids and preventive measures can be obtained from the following government Web sites:

- Environmental Protection Agency (EPA). Biosolids.

www.epa.gov/owm/bio.htm

(This site includes links to professional associations that address biosolids.)

- National Center for Infectious Diseases (NCID). Viral Hepatitis Resource Center. www.cdc.gov/ncidod/diseases/hepatitis

- National Institute for Occupational Safety and Health (NIOSH). www.cdc.gov/niosh 


\section{Bibliography}

Brugha R, Heptonstall J, Farrington P, Andren S, Perry K, Parry J [1998]. Risk of hepatitis A infection in sewage workers. Occup Environ Med 55(8):567-569.

CDC (Centers for Disease Control and Prevention) [1999]. Prevention of hepatitis A through active or passive immunization. MMWR 48(RR-12).

CFR. Code of Federal regulations. Washington, DC: U.S. Government Printing Office, Office of the Federal Register.

Clark CS [1987]. Health effects associated with wastewater treatment, disposal, and reuse. J Water Pollut Control Fed 59(6):436-440.

DeSerres G, Laliberté D [1997]. Hepatitis A among workers from a waste water treatment plant during a small community outbreak. Occup Environ Med 54(1):60-62.

Dorn RC, Reddy CS, Lamphere DN, Gaeuman JV, Lanese R [1985]. Municipal sludge application on Ohio farms: health effects. Environ Res 38:332-359.

EPA [2002]. Office of Inspector General status report: land application of biosolids. Washington, DC: Environmental Protection Agency, 2002-S-000004.

EPA [2000]. Guide to field storage of biosolids. Washington, DC: Environmental Protection Agency, Office of Wastewater Management, EPA/832-B-00-007.

EPA [1999]. Biosolids generation, use, and disposal in the United States. Washington, DC: Environmental Protection Agency, Office of Solid Waste, EPA530-R-99-009.

EPA [1999]. Environmental regulations and technology — control of pathogens and vector attraction in sewage sludge. Washington, DC: Environmental Protection Agency, Office of Research and Development, EPA/625/R-92/013.

EPA [1995]. Pathogen risk assessment methodology for municipal sewage sludge landfilling and surface disposal. Washington, DC: Environmental Protection Agency, Office of Research and Development, EPA/600/R-95/016.

Khuder SA, Arthur TA, Bisesi MS, Schaub EA [1998]. Prevalence of infectious disease and associated symptoms in wastewater treatment workers. Am J Ind Med 33:571-577.

Kowal NE, Pahren HR [1981]. Health effects associated with wastewater treatment and disposal. J Water Pollut Control Fed 53(6):776-786.

Laitinen S, Kangas J, Kotimaa M, Liesivouri J, Martikainen PJ, Nevalainen A, Sarantila R, Husman K [1994]. Workers' exposure to airborne bacteria and endotoxins at industrial wastewater treatment plants. Am Ind Hyg Assoc J 55(11):1055-1060.

Lodor ML [2001]. Viewpoint: NIOSH report omits significant details in LeSourdsville case. Biosolids Technical Bulletin, Water Environ Fed 7(4):11-13.

Lundholm M, Rylander R [1983]. Work-related symptoms among sewage workers. Br J Ind Med 40:325-329.

National Research Council [1996]. Use of reclaimed water and sludge in food crop production. Washington, DC: National Academy Press.

NIOSH [1999]. Hazard evaluation and technical assistance report: Bio-Solids Land Application Process, LeSourdsville, OH. Cincinnati, OH: U.S. Department of Health and Human Services, Public Health Service, Centers for Disease Control and Prevention, National 
Institute for Occupational Safety and Health, DHHS (NIOSH) Publication No. 98-0118-2748.

Pillai SD, Widmer KW, Dowd SE, Ricke SC [1996]. Occurrence of airborne bacteria and pathogen indicators during land application of sewage sludge. Appl Environ Microbiol 62:296-299.

Scarlett- Kranz JM, Babish JG, Strickland D, Lisk DJ [1987]. Health among municipal sewage and water treatment plant workers. Toxicol Ind Health 3(3):311-319.
Straub TM, Pepper IL, Gerba CP [1993]. Hazards from pathogenic microorganisms in land-disposed sewage sludge. Rev Environ Contamin Toxicol 132:55-91.

Trout D, Mueller MS, Venczel L, Krake A [2000]. Evaluation of occupational transmission of Hepatitis A virus among wastewater workers. J Occup Environ Med 42(1):83-87.

WEF [1994]. Safety and health in wastewater systems: manual of practice No. 1. Alexandria, VA:Water Environment Federation (WEF). 